\title{
Poliovirus advance sparks fears of data curbs
}

\section{Erika Check, Washington}

The recent laboratory synthesis of an infectious poliovirus is prompting fears among US biologists that the publication of results deemed potentially useful to terrorists may be restricted.

The virus was synthesized by a team led by virologist Eckard Wimmer at the State University of New York at Stony Brook. The results, published online by Science on 11 July (J. Cello, A. V. Paul \& E. Wimmer Science $10.1126 /$ science.1072266), sparked media reports worldwide suggesting that similar techniques might be used by terrorists to synthesize the Ebola virus or even smallpox.

Geneticists fear that the report - the first demonstration that a published genome can be turned into an infectious virus - will encourage calls for a clampdown on the open publication of gene sequences of viruses. US government officials have been floating the idea of such restrictions since the terrorist attacks last autumn (see Nature 414, 237-238; 2001).

The authors of the paper came under fire from some biologists for failing to offer any defence of the open publication of scientific data - or to discuss the wider context - in their paper. Critics argue that if restrictions on the publication of gene sequences are now implemented, they will cripple research into countering dangerous viruses.

"I'm very worried they're going to set off a rash of bills that would criminalize scientists," says Craig Venter, the former president of biotechnology company Celera Genomics in Rockville, Maryland, and now head of the J. Craig Venter Science Foundation, a non-profit group. Venter and other critics say that a harmless virus, rather than a human pathogen, could just as easily have

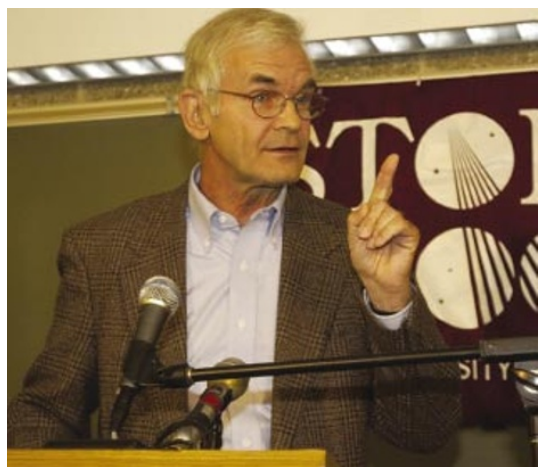

For Eckard Wimmer, his results brought a 'scary realization' that viruses can be recreated.

been used to demonstrate the technique.

Wimmer defends his group's decision to publish, saying that they are only pointing out the fact that terrorists could misuse published data. "We've been criticized for playing into the hands of a bioterrorist, but other groups have already written that this could be done," Wimmer says. He adds that all the information used in the experiment is already publicly available.

Wimmer's team started with the base-bybase sequence of polio's genome, which is made of RNA. But making RNA in a test tube is difficult, so the researchers bought DNA corresponding to the RNA from a company that makes synthetic genes on demand. They then used a naturally occurring enzyme to convert this DNA template into RNA. When added to a mixture of human proteins, the RNA copied itself and made new, infectious polioviruses.

Wimmer has previously synthesized infectious polioviruses, but used RNA isolated from wild polioviruses, not from raw

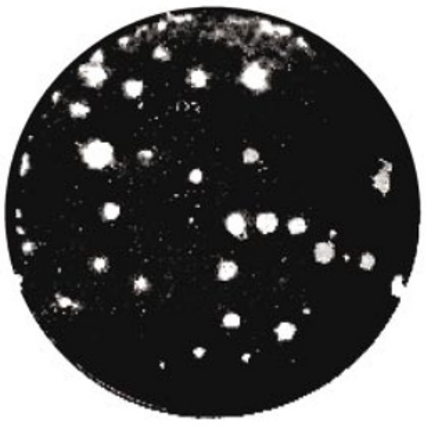

Culture shock: researchers have synthesized this infectious poliovirus in the laboratory.

sequence information. He claims that the latest research proves that the world can never stop vaccinating against polio. "You cannot eliminate a virus from existence," he says. "Somebody can always resynthesize it, and that's a scary realization."

Experts say that it would be difficult but not impossible - to use Wimmer's method to synthesize a large and complicated virus, such as smallpox. And because pox viruses carry their own replication machinery they cannot co-opt human enzymes to reproduce themselves. This means that it would be impossible to recreate infectious smallpox using just viral DNA in an extract from human cells, says Geoffrey Smith, a virologist at Imperial College, London.

But Smith and others say that this problem might be solved by adding replication enzymes from a different pox virus to the mixture. And, they add, it would be relatively easy to recreate smaller viruses such as HIV or Ebola using Wimmer's method.

\section{Monkey smallpox trial suspended over painkiller use}

\section{Erika Check, Washington}

A study of smallpox in monkeys has been suspended by the Centers for Disease

Control and Prevention (CDC) in Atlanta, Georgia, because of concerns about animal treatment.

The study, which began last year, is led by virologist Peter Jahrling of the US Army Medical Research Institute of Infectious Diseases in Fort Detrick, Maryland. Jahrling infected cynomolgus macaques with two strains of smallpox virus in an attempt to develop a monkey model for testing new therapies for the disease. But last week, the CDC suspended the study after Jahrling and veterinarians clashed over when the monkeys should receive painkillers.
The Food and Drug Administration (FDA) ruled in May that animal studies can be used to obtain regulatory approval for drugs (such as smallpox therapies) that cannot ethically be tested on humans. Jahrling says he expects the FDA will require experimental treatments to be given without painkillers, and doesn't want to press on with a study that might be ineligible for approval.

A CDC spokesperson says that the institution's animal-care committee had mandated that all the animals in the study should receive painkillers at a certain point, but "word had not gotten to all the vets involved". The spokesperson says that the agency hopes to resolve the issue at a meeting with institute researchers on 16 July.

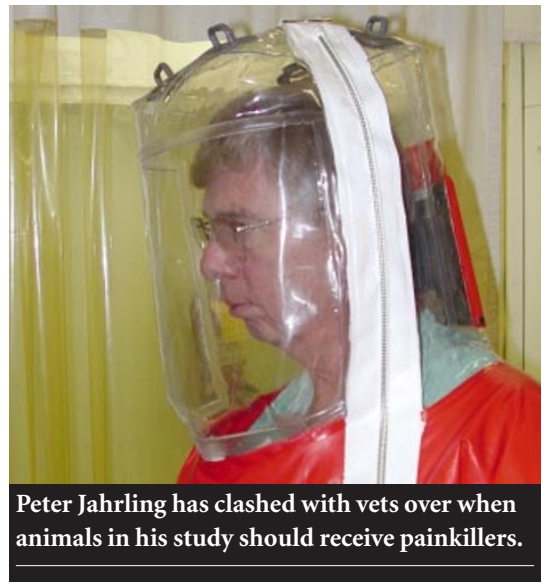

